\title{
Response of AquaCrop Model to Different Irrigation Schedules for Irrigated Cabbage
}

\author{
G. S. Pawar ${ }^{1}$ M. U. Kale ${ }^{1} \cdot$ J. N. Lokhande ${ }^{1}$
}

Received: 17 February 2016/Accepted: 29 August 2016/Published online: 21 November 2016

(C) The Author(s) 2016. This article is published with open access at Springerlink.com

\begin{abstract}
Agricultural sector faces the challenge to produce more food with less water by increasing crop water productivity. As such, the question of improving the present level of crop water productivity in general and for irrigation in particular assumes a great significance in perspective water resource planning. This study was undertaken to improve water productivity, i.e., 'more crop per drop.' In this study response of cabbage to different irrigation schedules under mulch and non-mulch condition using calibrated AquaCrop model was evaluated. AquaCrop is a crop model that simulates yield response to water developed by FAO and is appropriate to consider effects where water is the limiting factor for crop production. AquaCrop was calibrated for cabbage (Brassica oleracea var. capitata), a leafy vegetable. Simulations were carried out for the period November 27, 2013, to February 19, 2014 with $\mathrm{T}_{1}, \mathrm{~T}_{2}, \mathrm{~T}_{3}$ (treatments irrigation scheduling at $50 \%$ moisture depletion of available water capacity under black, silver, and no polyethylene mulch with drip irrigation) and $\mathrm{T}_{4}, \mathrm{~T}_{5}, \mathrm{~T}_{6}$ (irrigation scheduling at $100 \%$ evapotranspiration under black, silver, and no polyethylene mulch with drip irrigation). The model provided excellent simulation of canopy and yield. The harvest index was observed as $80 \%$ for cabbage. Formulated Schedule with $\mathrm{S}_{1}, \mathrm{~S}_{2}, \mathrm{~S}_{3}, \mathrm{~S}_{4}$, and $\mathrm{S}_{5}$ (irrigation schedule at 110, 90, 80, 70, and $60 \% \mathrm{ET}_{\mathrm{c}}$ ) and $\mathrm{S}_{6}, \mathrm{~S}_{7}$, $\mathrm{S}_{8}, \mathrm{~S}_{9}$, and $\mathrm{S}_{10}$ (mulch + Irrigation schedule at 110, 90, 80, 70 and $60 \% \mathrm{ET}_{\mathrm{c}}$ ). $\mathrm{S}_{8}$ saved $25.19 \%$ water with only $4.63 \%$ reduction in the yield of cabbage head compared to control and resulted in water use efficiency as $6.05 \mathrm{~kg} \mathrm{~m}^{-3}$. Thus $\mathrm{S}_{8}$ is recommended to be used for cabbage production, to water productivity.
\end{abstract}

Keywords Crop productivity $\cdot$ Water use efficiency $\cdot$ AquaCrop $\cdot$ Cabbage

\section{Introduction}

The great challenge of the agricultural sector is to produce more food from less water. With rapidly growing population, the pressure on limited fresh water resources increases. Estimation of water requirement of crop is essential for crop planning on farm and, for designing and monitoring irrigation projects. Prediction methods for crop water requirements are used owing to difficulty of obtaining accurate field measurements. Food and Agriculture Organisation (FAO) has given guidelines to calculate crop water requirements of

\section{G. S. Pawar}

agroneer.ganesh17@gmail.com

1 Department of Irrigation and Drainage Engg., Dr. Panjabrao Deshmukh Krishi Vidyapith, Akola, Maharashtra, India crop under different climatic and agronomic conditions. Methods often need to be applied for such climatic and agronomic conditions, which are different from those under which they were originally developed. Testing the accuracy of methods under a new set of conditions is laborious and time consuming. Therefore, use of available computer software with appropriate modifications to suit the site conditions may be a better option.

Small-scale irrigation initiatives are expanding rapidly in Maharashtra. However, in many cases optimal yields are not being obtained despite the available water and required nutrient applications. Local stakeholders need an easy-touse decision-support tool to assess irrigation water use and its impact on yield. A very powerful option to identify potential yields and possible crop cultivation constraints of particular areas are crop modeling tools [7]. Use of models 
can assist in evaluating and reducing time intensive and expensive field tests [19]. Model results with regard to crop performance, management, and yield estimates will help decision makers to decide which management system is suited best for a particular field, by estimating the yield and crop water productivity optimum. Frequently applied crop yield models are: CropSyst, CERES, DSSAT, EPIC, CropWat, SWAP/WOFOST, and AquaCrop [11].

AquaCrop simulates crop yield response to water and is particularly suited to address conditions where water is a key limiting factor in crop production. AquaCrop is developed from revision of 'FAO Irrigation and Drainage Paper No. 33 Yield Response to Water' (Doorenbos and Kassam 1979, [5]. AquaCrop attempts to balance accuracy, simplicity, and robustness. AquaCrop is the successor of CropWat featuring new adjustment options to reproduce crop environment in more detail. The capacity of AquaCrop model in simulating the yield in response to water is proved by various researchers $[1,3,4,8,10,16,18]$, etc. Cabbage (Brassica oleracea var. capitata) is one of the important vegetable crops in Maharashtra State. Average annual production of cabbage in India is 8395.01 thousand tons and in Maharashtra is 421.00 thousand tons [National Horticulture Board (NHB) [14]. Productivity of cabbage in India, Maharashtra, and Vidarbha region is 22.04, 21.10, and $20.00 \mathrm{tha}^{-1}$, respectively. It is clear that the productivity in Vidarbha region is too less as compared to national level. Conventionally, cabbage is irrigated with flood irrigation method. The effect of drip irrigation on yield of cabbage under mulch and non-mulch condition is studied. Higher yield was obtained for drip irrigation with black plastic mulch $111.72 \mathrm{tha}^{-1}$ as compare to $106.68 \mathrm{tha}^{-1}$ for full volume of irrigation met with drip. Use of drip irrigation either alone or in combination with mulch can increase cabbage yield significantly over furrow irrigation to tune of $65 \%$. The highest yield per unit quantity of water used was $427.04 \mathrm{~kg} \mathrm{ha}^{-1} \mathrm{~mm}^{-1}$ for the treatment $60 \%$ of full water requirement with black mulch. The cost-benefit ratio is 8.17 for furrow irrigation treatment with full volume followed by 6.99 for $60 \%$ of full volume of irrigation met with drip [17].

Taking into account the importance of water productivity, this research project was undertaken with following objectives. To calibrate and validate AquaCrop model for cabbage and to predict the response of cabbage to different irrigation schedules using validated model.

\section{Materials and Methods}

\section{Data Collection}

\section{Meteorological Data}

Meteorological data for the period November 2013 to February 2014 was obtained from Agro-meteorological

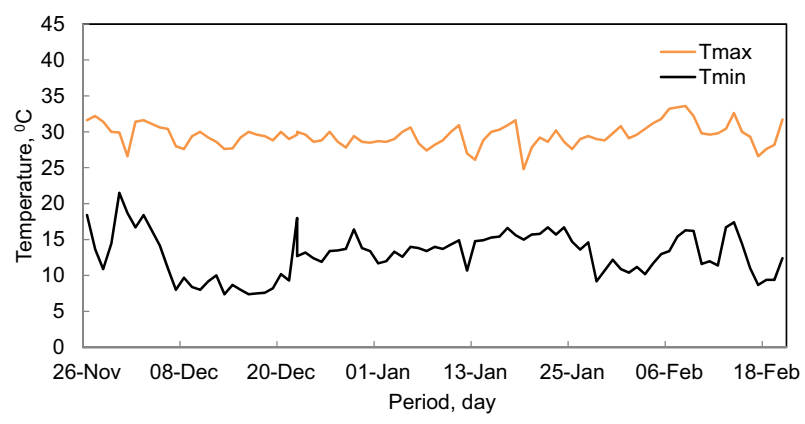

Fig. 1 Variation of maximum and minimum temperature

Observatory, Department of Agronomy, Dr. P.D.K.V., Akola. It comprised of maximum and minimum temperature $\left({ }^{\circ} \mathrm{C}\right)$, mean daily relative humidity $(\%)$, daily sunshine hours $(\mathrm{hr})$, wind speed $\left(\mathrm{ms}^{-1}\right)$, rainfall $(\mathrm{mm})$, and evaporation $\left(\mathrm{mm} \mathrm{day}^{-1}\right)$ (Fig. 1).

\section{Crop Data}

Crop-specific parameters required by AquaCrop model are plant density, yield, biomass, harvest index (HI), effective rooting depth, crop growth stages and green canopy cover (CC), while user-specific parameters required are crop cultivar, timing of crop cycle, water management, and agronomic practices.

The required data such as was obtained from a field experiment conducted in the Department of Irrigation and Drainage Engineering, Dr P.D.K.V Akola, India during the year 2013-2014 (Fig. 2).

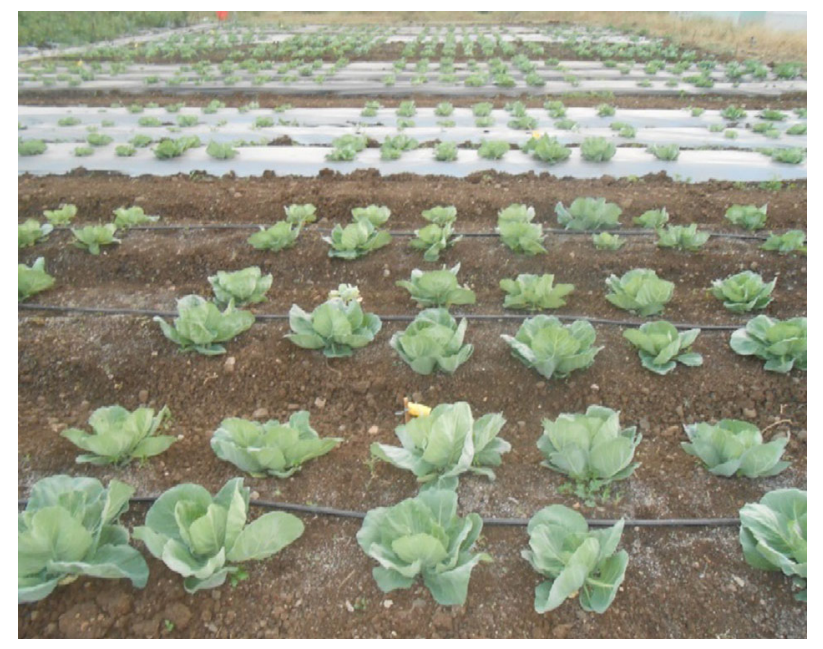

Fig. 2 Experimental plot of cabbage 
The experiment consists of following treatments.

\begin{tabular}{ll}
\hline Treatment & Specifications \\
\hline $\mathrm{T}_{1}$ & $\begin{array}{c}\text { Irrigation scheduling at } 50 \% \text { moisture depletion of } \\
\text { available water capacity under black polyethylene } \\
\text { mulch with drip irrigation }\end{array}$ \\
$\mathrm{T}_{2} \quad \begin{array}{l}\text { Irrigation scheduling at } 50 \% \text { moisture depletion of } \\
\text { available water capacity under silver polyethylene } \\
\text { mulch with drip irrigation }\end{array}$ \\
$\mathrm{T}_{3} \quad \begin{array}{l}\text { Irrigation scheduling at } 50 \% \text { moisture depletion of } \\
\text { available water capacity with drip irrigation }\end{array}$ \\
$\mathrm{T}_{4} \quad \begin{array}{c}\text { Irrigation scheduling at } 100 \% \text { crop evapotranspiration } \\
\text { under black polyethylene mulch with drip irrigation }\end{array}$ \\
$\mathrm{T}_{5} \quad \begin{array}{c}\text { Irrigation scheduling at } 100 \% \text { crop evapotranspiration } \\
\text { under silver polyethylene mulch with drip irrigation }\end{array}$ \\
$\mathrm{T}_{6} \quad \begin{array}{l}\text { Irrigation scheduling at } 100 \% \text { crop evapotranspiration } \\
\text { with drip irrigation }\end{array}$ \\
\end{tabular}

\section{Soil Data}

To characterize the soil at experimental plot, soil profile study was carried out. Soil samples were collected from respective soil horizons for physicochemical analysis and results are presented in Table 1.

\section{Brief Description of Model}

The complexity of crop responses to water deficits led to the use of empirical production functions as the most practical option to assess crop yield response to water. Among the empirical function approaches, FAO Irrigation and Drainage Paper No. 33 [6] represented an important source to determine the crop yield response to water through the following equation:

$$
\left(1-\frac{\mathrm{Ya}}{\mathrm{Yx}}\right)=\mathrm{ky}\left(1-\frac{\mathrm{ETa}}{\mathrm{ETx}}\right)
$$

where

Yx and Ya-Maximum and actual yield, ETx and ETa-Maximum and actual evapotranspiration, and kyCrop yield factor

\section{Calibration and Validation of Model}

Part of the obtained field data, i.e., data for full irrigation treatment (100\% $\mathrm{ET}_{\mathrm{c}}$ under non-mulch- $\mathrm{T}_{6}$ ) was used for calibration of the model, while the remaining data were used to validate the model. AquaCrop version 4.0 was used in the study.

The model was calibrated by varying parameters such as canopy cover, water productivity, and harvesting index.

\section{Model Performance}

Nash-Sutcliffe coefficient and a dimensionless statistical measure, i.e., coefficient of residual mass were used to judge the performance of the model.

\section{Nash-Sutcliffe Coefficient of Efficiency}

Nash-Sutcliffe coefficient of efficiency $\left(\mathrm{R}_{\mathrm{NS}}^{2}\right)$ is used to assess predictive power of hydrological models. $\mathrm{R}_{\mathrm{NS}}^{2}$ is described by following formula [13].

$R_{\mathrm{NS}}^{2}=1-\frac{\sum\left(Q_{\mathrm{O}}-Q_{\mathrm{S}}\right)^{2}}{\sum\left(Q_{\mathrm{O}}-Q_{\mathrm{av}}\right)^{2}}$

where, $Q_{o}$-observed values; $Q_{s}$-simulated values; $Q_{a v}-$ mean of observed values.

\section{Coefficient of Residual Mass (CRM)}

CRM is a dimensionless statistical performance criterion as described below.

$\mathrm{CRM}=\frac{\left[\sum_{\mathrm{i}=1}^{\mathrm{n}} \mathrm{O}_{\mathrm{i}}-\sum_{\mathrm{i}=1}^{\mathrm{n}} \mathrm{S}_{\mathrm{i}}\right]}{\sum_{\mathrm{i}=1}^{\mathrm{n}} \mathrm{O}_{\mathrm{i}}}$

where

$\mathrm{O}_{\mathrm{i}}$ - observed value at time $\mathrm{i} ; \mathrm{S}_{\mathrm{i}}$ - simulated value at time i.

Table 1 Physical properties and soil moisture constants for soil at experimental site

\begin{tabular}{|c|c|c|c|c|c|c|c|c|c|c|}
\hline \multirow{2}{*}{$\begin{array}{l}\text { Soil } \\
\text { Horizon }\end{array}$} & \multirow{2}{*}{$\begin{array}{l}\text { Soil depth } \\
\mathrm{cm}\end{array}$} & \multirow{2}{*}{ Sand \% } & \multirow[t]{2}{*}{ Silt \% } & \multirow[t]{2}{*}{ Clay \% } & \multirow{2}{*}{$\begin{array}{l}\text { Textural } \\
\text { class }\end{array}$} & \multirow{2}{*}{$\begin{array}{l}\text { Bulk density } \\
\mathrm{gcm}^{-3}\end{array}$} & \multicolumn{2}{|c|}{ Water retention at, $\mathrm{cm}^{3} \mathrm{~cm}^{-3}$} & \multirow{2}{*}{$\begin{array}{l}\text { Saturated moisture } \\
\text { content, } \\
\mathrm{cm}^{3} \mathrm{~cm}^{-3}\end{array}$} & \multirow[t]{2}{*}{$\mathrm{K}_{\mathrm{s}}, \mathrm{cmday}^{-1}$} \\
\hline & & & & & & & 0.33 bar & 15 bar & & \\
\hline Ap & $0-18$ & 10.2 & 31 & 58.8 & Clay & 1.25 & 0.34 & 0.18 & 0.51 & 25.84 \\
\hline A & $18-42$ & 9.6 & 30.2 & 60.2 & Clay & 1.26 & 0.35 & 0.20 & 0.51 & 25.50 \\
\hline $\mathrm{C}$ & $42-68$ & 50.3 & 12.4 & 37.3 & Sandy clay & 1.35 & 0.26 & 0.15 & 0.40 & 11.48 \\
\hline
\end{tabular}


Table 2 Formulated irrigation schedules

\begin{tabular}{ll}
\hline Schedule & Particular \\
\hline Non-Mulch Treatment & Irrigation scheduling at $110 \%$ of crop evapotranspiration $\left(\mathrm{ET}_{\mathrm{c}}\right)$ with drip irrigation \\
$\mathrm{S}_{1}$ & Irrigation scheduling at $90 \%$ of crop evapotranspiration $\left(\mathrm{ET}_{\mathrm{c}}\right)$ with drip irrigation \\
$\mathrm{S}_{2}$ & Irrigation scheduling at $80 \%$ of crop evapotranspiration $\left(\mathrm{ET}_{\mathrm{c}}\right)$ with drip irrigation \\
$\mathrm{S}_{3}$ & Irrigation scheduling at $70 \%$ of crop evapotranspiration $\left(\mathrm{ET}_{\mathrm{c}}\right)$ with drip irrigation \\
$\mathrm{S}_{4}$ & Irrigation scheduling at $60 \%$ of crop evapotranspiration $\left(\mathrm{ET}_{\mathrm{c}}\right)$ with drip irrigation \\
$\mathrm{S}_{5}$ & \\
$\mathrm{Mulch}$ Treatment & Irrigation scheduling at $110 \%$ of crop evapotranspiration $\left(\mathrm{ET}_{\mathrm{c}}\right)$ under polyethylene mulch with drip irrigation \\
$\mathrm{S}_{6}$ & Irrigation scheduling at $90 \%$ of crop evapotranspiration $\left(\mathrm{ET}_{\mathrm{c}}\right)$ under polyethylene mulch with drip irrigation \\
$\mathrm{S}_{7}$ & Irrigation scheduling at $80 \%$ of crop evapotranspiration $\left(\mathrm{ET}_{\mathrm{c}}\right)$ under polyethylene mulch with drip irrigation \\
$\mathrm{S}_{8}$ & Irrigation scheduling at $70 \%$ of crop evapotranspiration $\left(\mathrm{ET}_{\mathrm{c}}\right)$ under polyethylene mulch with drip irrigation \\
$\mathrm{S}_{9}$ & Irrigation scheduling at $60 \%$ of crop evapotranspiration $\left(\mathrm{ET}_{\mathrm{c}}\right)$ under polyethylene mulch with drip irrigation \\
$\mathrm{S}_{10}$ &
\end{tabular}

\section{Formulation of Irrigation Schedules}

Daily reference $\mathrm{ET}_{\mathrm{o}}$ was estimated using modified Penman-Monteith equation [2]. Crop evapotranspiration was computed on daily basis using values of crop coefficients, for cabbage referred from $[9,15]$. Ten schedules were formulated considering various levels of water application and mulch in combination as follows (Table 2).

\section{Effectiveness of Formulated Schedules}

The calibrated model was used to evaluate the impacts of different irrigation schedules on performance of cabbage. Water use efficiency (WUE) refers to the ratio between the total yield of irrigated cabbage and total irrigation water applied [12].

$\mathrm{WUE}=\frac{\text { Total irrigated cabbage yield, } \mathrm{kg}}{\text { Total irrigation water applied, } \mathrm{m}^{3}}$.

\section{Results and Discussion}

\section{Calibration and Validation of AquaCrop Model}

Calibration and validation of FAO crop water productivity model, i.e., AquaCrop in terms of canopy cover, biomass and yield. Model performance and effectiveness of developed alternative delivery schedules was also evaluated based on water use efficiency.

\section{Calibration of AquaCrop Model}

AquaCrop model was calibrated for the period from November 27, 2013, to February 20, 2014, i.e., crop period, using field data for full irrigation treatment (i.e., irrigation scheduling at $100 \%$ ETc under non-mulch- $\mathrm{T}_{6}$ ). To judge the performance of model, observed values of model parameters, i.e., canopy cover (CC), biomass and yield of cabbage were compared with simulated outputs. The performance of model is discussed in the following sections (Fig. 3).

Canopy parameters, i.e., initial canopy cover, canopy size of transplanted seedling, number of days to recover; maximum canopy cover and canopy cover decline, were adjusted manually during the calibration process.

Figure 4 shows that there is close match between observed and simulated canopy cover. It is supported by high value of $R_{\mathrm{NS}}^{2}(0.96)$. Another statistical parameter, i.e., CRM having value as -0.067 , indicates that the model overestimates the canopy cover. From Fig. 4 it is clear that the canopy cover was overestimated by model particularly during 36-64 DAT, i.e., during development stage. But, the scatter plot clears that as the canopy cover lie on both sides of 1:1 line, there is no consistent over or under estimation.

Figure 5 shows that the model overestimate biomass though the value of $\mathrm{R}_{\mathrm{NS}}^{2}$ is high as 0.96 . It is supported by another statistical criterion, i.e., CRM with value of -0.122 indicating model overestimate the biomass, in general. From Fig. 5 it is clear that the biomass was overestimated by model particularly during 30 to 75 DAT.

Cabbage head yield was observed as $14.31 \mathrm{t} \mathrm{ha}^{-1}$ for calibration period. For harvesting index of $80 \%$, the model predicted yield was $14.27 \mathrm{t} \mathrm{ha}^{-1}$. Nash-Sutcliffe coefficient as 0.98 indicates that the observed and simulated yields were in close match. Coefficient of residual mass as 0.084 indicates that the model slightly underestimates the yield.

Above results showed that the model calibration was satisfactory as the observed and simulated values of canopy cover, biomass, and cabbage yield matched well. Also $R_{\mathrm{NS}}^{2}$ and CRM statistics were acceptable. Hence, the AquaCrop model setup was considered as calibrated (Fig. 6). 


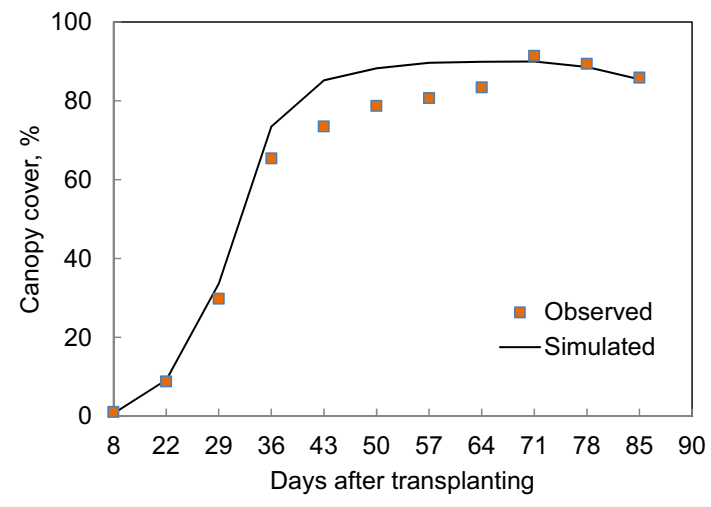

Fig. 3 Observed and simulated canopy cover for calibration period

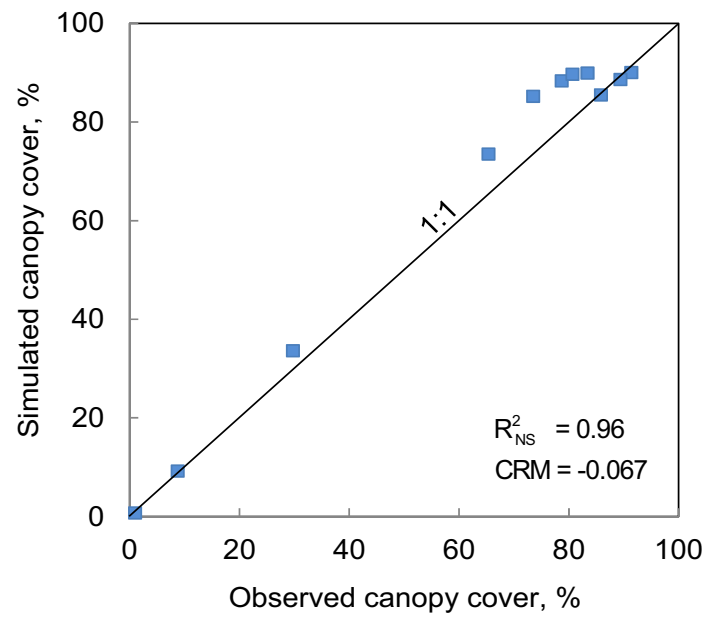

Fig. 4 Comparison between observed and simulated canopy cover for calibration period

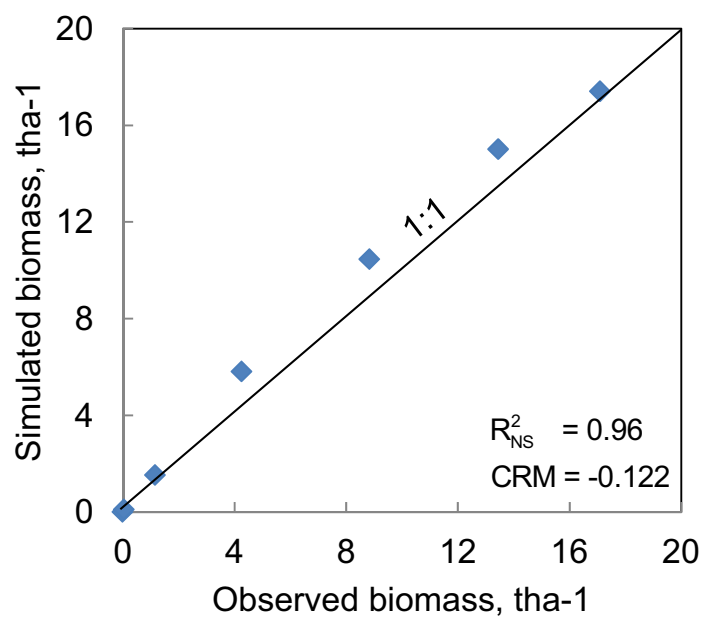

Fig. 5 Comparison between observed and simulated biomass for calibration period

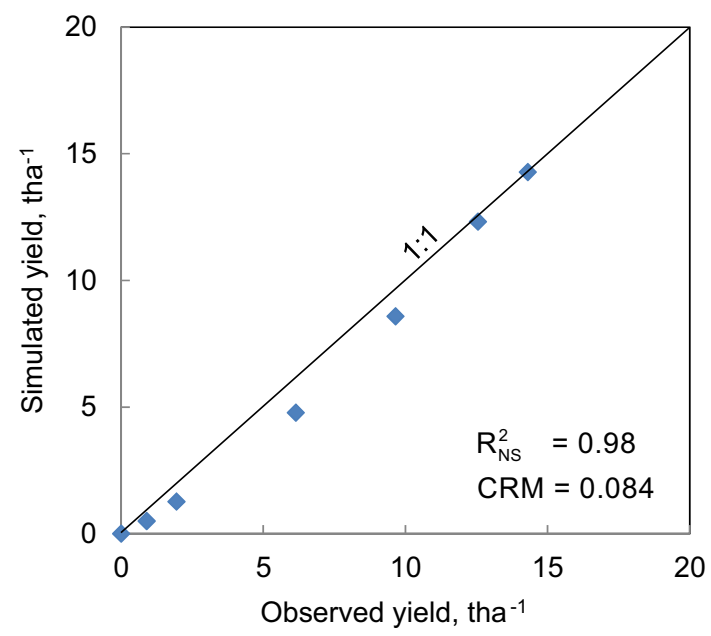

Fig. 6 Comparison between observed and simulated yield for calibration period

\section{Model Validation}

Model validation is in fact the extension of calibration process. Thus validation was carried out without any further adjustments to the calibrated model parameters. The model was validated for the period November 27, 2013 to February 20, 2014 for the remaining treatments, i.e., $\mathrm{T}_{1}$ to $\mathrm{T}_{5}$. The cumulative yield and biomass for validation period for each treatment were simulated with model, and Table 3 presents the results of statistical tests for validation period.

The biomass varied between 13.50 and $17.10 \mathrm{t} \mathrm{ha}^{-1}$, whereas yield of cabbage varied between 9.90 and $13.46 \mathrm{tha}^{-1}$. The average variation between observed and simulated biomass is $-1.79 \%$, while average variation in yield is found to be $-1.35 \%$.

Nash-Sutcliffe coefficient $\left(\mathrm{R}_{\mathrm{NS}}^{2}\right)$ values are found as 0.96 for biomass and 0.93 for cabbage yield which shows close match between observed and simulated biomass and yield, respectively. Coefficient of Residual Mass (CRM) is found as -0.018 and -0.013 for biomass and yield, respectively, indicates that model overestimates the biomass and yield, likewise during calibration.

The comparison of observed and simulated values of biomass and yield for validation period are presented in Fig. 7.

As simulated values lie on both side of 1:1 line, it is cleared that the model does not overestimate or underestimate the parameters consistently. Considering overall acceptability of validation results, it is concluded that the model performs well with relatively high validity. 
Table 3 Statistical analysis of validated results for biomass and yield

\begin{tabular}{|c|c|c|c|c|c|}
\hline \multirow[t]{2}{*}{ Sr. no. } & \multirow[t]{2}{*}{ Treatments } & \multicolumn{2}{|c|}{ Biomass, tha ${ }^{-1}$} & \multicolumn{2}{|c|}{ Yield, tha ${ }^{-1}$} \\
\hline & & Observed & Simulated & Observed & Simulated \\
\hline 1 & $\mathrm{~T}_{1}$ & 13.50 & 13.62 & 10.07 & 9.94 \\
\hline 2 & $\mathrm{~T}_{2}$ & 15.25 & 15.46 & 12.62 & 12.37 \\
\hline 3 & $\mathrm{~T}_{3}$ & 14.20 & 14.47 & 09.90 & 10.71 \\
\hline 4 & $\mathrm{~T}_{4}$ & 17.00 & 17.44 & 13.20 & 13.43 \\
\hline 5 & $\mathrm{~T}_{5}$ & 17.10 & 17.44 & 13.46 & 13.60 \\
\hline $\mathrm{R}_{\mathrm{NS}}^{2}$ & & 0.96 & & 0.93 & \\
\hline CRM & & -0.018 & & -0.013 & \\
\hline
\end{tabular}
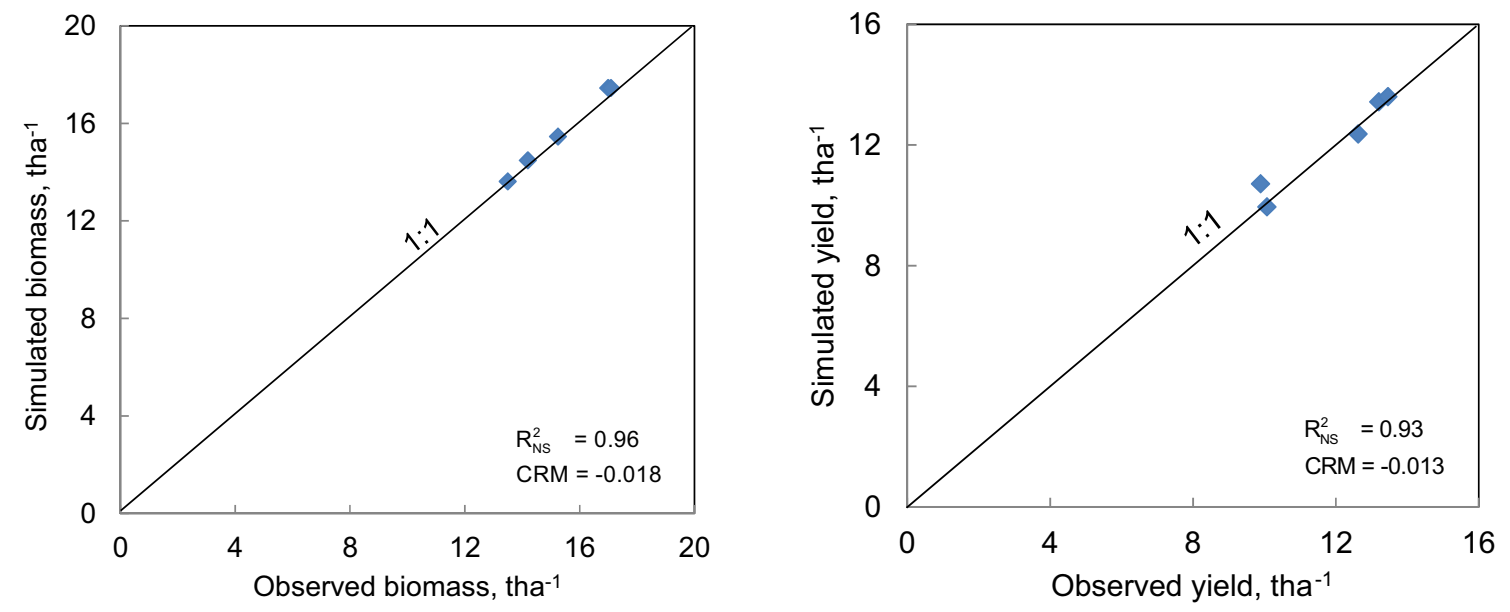

Fig. 7 Comparison between observed and simulated yield and biomass for validation

\section{Effectiveness of Developed Alternative Irrigation Schedules}

To optimize irrigation schedule, water use efficiency (WUE) for different developed irrigation schedules was calculated (Eq. 4) using water applied and simulated yield; presented in Table 4.

In case of first set of irrigation schedules, i.e., from $S_{1}$ to $\mathrm{S}_{5}$, WUE varied from 5.02 to $5.55 \mathrm{~kg} \mathrm{~m}^{-3}$. Schedule $\mathrm{S}_{5}$ resulted in maximum WUE, i.e., $5.55 \mathrm{~kg} \mathrm{~m}^{-3}$, while schedule $S_{1}$ resulted in the lowest WUE, i.e., 5.02 $\mathrm{kg} \mathrm{m}^{-3}$.

In second set of irrigation schedules, i.e., from $S_{6}$ to $S_{10}$, WUE varied from 5.16 to $6.91 \mathrm{~kg} \mathrm{~m}^{-3}$. Schedule $S_{10}$ resulted in maximum WUE, i.e., $6.91 \mathrm{~kg} \mathrm{~m}^{-3}$, while schedule $S_{6}$ resulted in the lowest WUE, i.e., $5.16 \mathrm{~kg} \mathrm{~m}^{-3}$. In general, water use efficiency increases as the water applied decreases.

Figure 8 shows the variation of yield against water applied for developed schedules.

From Fig. 8, it is clear that if water applied decreases by $41.70 \%$, the yield of cabbage decreased by $44.14 \%$. It is cleared that as water applied decreases, the rate of reduction in the yield decreases gradually. From the table it is also clear that the cabbage is very sensitive to water applied.

It is also clear that in case of second set of developed schedules, i.e., schedules for mulched condition, as water applied decreases, yield of cabbage also decreases, but the rate of decrease in the yield is less as compare to Set I schedules. Table 4 also confirms that the yield of cabbage is increased under mulch condition as compare non-mulch condition, irrespective of schedule.

Maximum WUE was observed for schedule $\mathrm{S}_{10}$. Schedule $\mathrm{S}_{10}$ saved $41.70 \%$ of water, but yield of cabbage reduced by $21.20 \%$. Schedule $\mathrm{S}_{8}$ saved $25.19 \%$ water and resulted in only $4.63 \%$ reduction in the yield as compared to control treatment. In case of schedule $S_{7}$, with saving of $10 \%$ water over control treatment, yield was increased by $1.41 \%$. Though yield was increased, water use efficiency decreased. Taking into account these facts, a soil moisture status in the soil was studied with output of calibrated model. The model generated transpiration, canopy cover, and soil moisture in the rootzone for schedule S8 and S10 are depicted in Figs. 9 and 10, respectively. 
Table 4 Water use efficiency for different schedules

\begin{tabular}{|c|c|c|c|c|c|}
\hline Schedule & $\begin{array}{l}\text { Water applied } \\
(\mathrm{cm})\end{array}$ & $\begin{array}{l}\text { Simulated yield } \\
\left(\mathrm{q} \mathrm{ha}{ }^{-1}\right)\end{array}$ & $\begin{array}{l}\text { Variation in water } \\
\text { applied }(\%)\end{array}$ & $\begin{array}{l}\text { Variation } \\
\text { in yield }(\%)\end{array}$ & $\begin{array}{l}\text { Water use efficiency, } \\
\left(\mathrm{kg} \mathrm{m}^{-3}\right)\end{array}$ \\
\hline \multicolumn{6}{|l|}{ Non-mulch treatments } \\
\hline Control, $100 \% \mathrm{ET}_{\mathrm{c}}$ & 24.7 & 143.11 & - & - & - \\
\hline $\mathrm{S}_{1}\left(110 \% \mathrm{ET}_{\mathrm{c}}\right)$ & 26.6 & 133.55 & -7.69 & 6.68 & 5.02 \\
\hline $\mathrm{S}_{2}\left(90 \% \mathrm{ET}_{\mathrm{c}}\right)$ & 22.1 & 114.19 & 10.53 & 20.21 & 5.17 \\
\hline $\mathrm{S}_{3}\left(80 \% \mathrm{ET}_{\mathrm{c}}\right)$ & 19.9 & 103.07 & 19.43 & 27.98 & 5.18 \\
\hline $\mathrm{S}_{4}\left(70 \% \mathrm{ET}_{\mathrm{c}}\right)$ & 17.3 & 92.75 & 29.96 & 35.19 & 5.36 \\
\hline $\mathrm{S}_{5}\left(60 \% \mathrm{ET}_{\mathrm{c}}\right)$ & 14.4 & 79.94 & 41.70 & 44.14 & 5.55 \\
\hline \multicolumn{6}{|l|}{ Mulch treatments } \\
\hline Control, $100 \% \mathrm{ET}_{\mathrm{c}}$ & 24.7 & 126.25 & - & - & - \\
\hline $\mathrm{S}_{6}\left(110 \% \mathrm{ET}_{\mathrm{c}}\right)$ & 26.6 & 137.22 & -7.69 & -8.69 & 5.16 \\
\hline $\mathrm{S}_{7}\left(90 \% \mathrm{ET}_{\mathrm{c}}\right)$ & 22.1 & 128.03 & 10.53 & -1.41 & 5.79 \\
\hline $\mathrm{S}_{8}\left(80 \% \mathrm{ET}_{\mathrm{c}}\right)$ & 19.9 & 120.41 & 19.43 & 4.63 & 6.05 \\
\hline $\mathrm{S}_{9}\left(70 \% \mathrm{ET}_{\mathrm{c}}\right)$ & 17.3 & 111.37 & 29.96 & 11.79 & 6.44 \\
\hline $\mathrm{S}_{10}\left(60 \% \mathrm{ET}_{\mathrm{c}}\right)$ & 14.4 & 99.49 & 41.70 & 21.20 & 6.91 \\
\hline
\end{tabular}

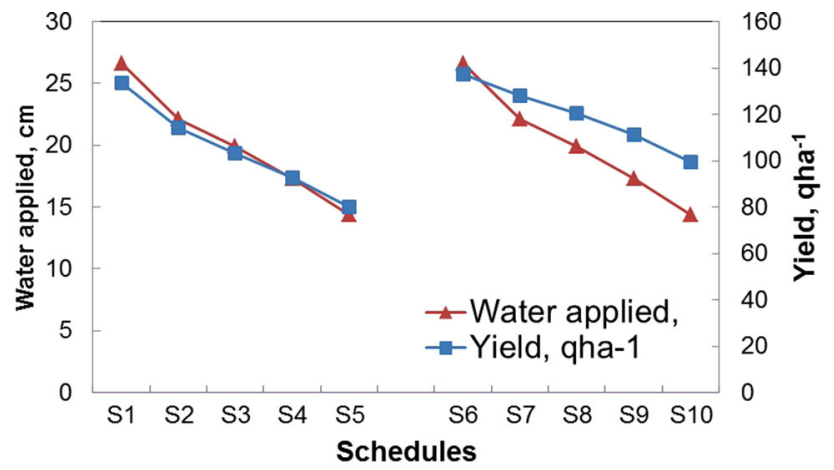

Fig. 8 Variation of yield against water applied

Figure 9 shows that up to first 30 days, soil moisture in the rootzone is at field capacity. Afterward it gradually decreases till the end of crop period. Throughout the crop period soil moisture is within available water capacity. The transpiration matched with that for full irrigation schedule (i.e., $100 \%$ ETc) during first 60 days. Later on transpiration decreases during last 30 days as compare to that for full irrigation schedule and that's why yield reduced by $4.63 \%$. The canopy cover matched with that for full irrigation schedule.

Figure 10 shows that up to first 20 days, soil moisture in the rootzone is at field capacity. Afterward it gradually decreases from 20 to 40 days after transplanting, and then it is more or less constant. Throughout the crop period soil moisture is within available water capacity. The transpiration matched with that for full irrigation schedule (i.e., $100 \%$ ETc) during first 35 days. Later on transpiration decreases gradually till end of crop period as compared to that for full irrigation schedule and that is why yield reduced by $21.20 \%$. The canopy cover also decreases from 35 to 90 days after transplanting.

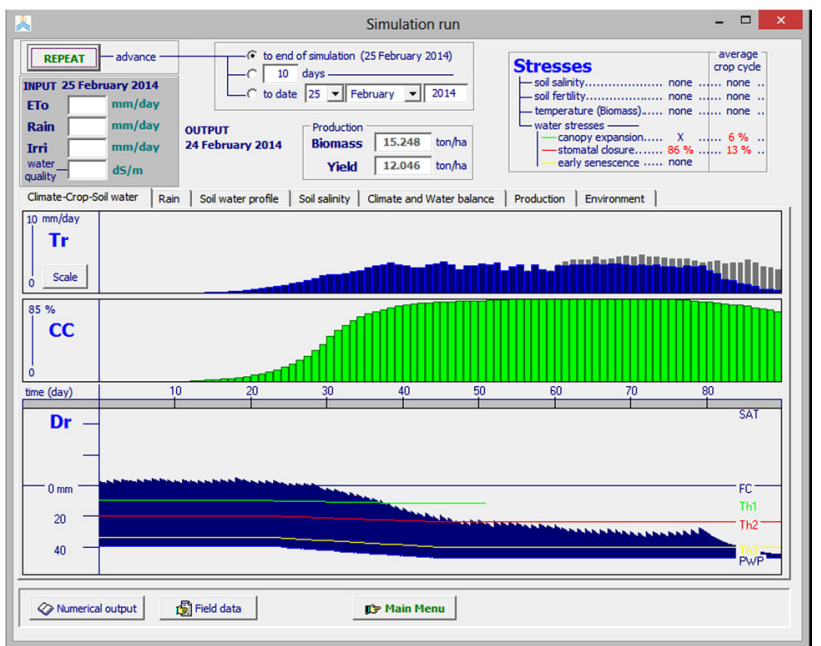

Fig. 9 Model generated transpiration, canopy cover, and soil moisture in the rootzone for schedule $S_{8}$

Thus it is clear that for schedule $\mathrm{S}_{8}$ soil moisture status in rootzone canopy cover and transpiration is better as compared to that for schedule $\mathrm{S}_{10}$.

As schedule $\mathrm{S}_{8}$ (mulch + Irrigation schedule at $80 \%$ ETc) saved $25.19 \%$ water with only $4.63 \%$ reduction in the yield of cabbage head as compared to control, it should be used for cabbage production.

\section{Summary and Conclusions}

Irrigated agriculture is the largest water-consuming sector, and it faces competing demands from other sectors, like industrial and domestic. Increasing demand and scarcity of water makes it important to use available water in most 


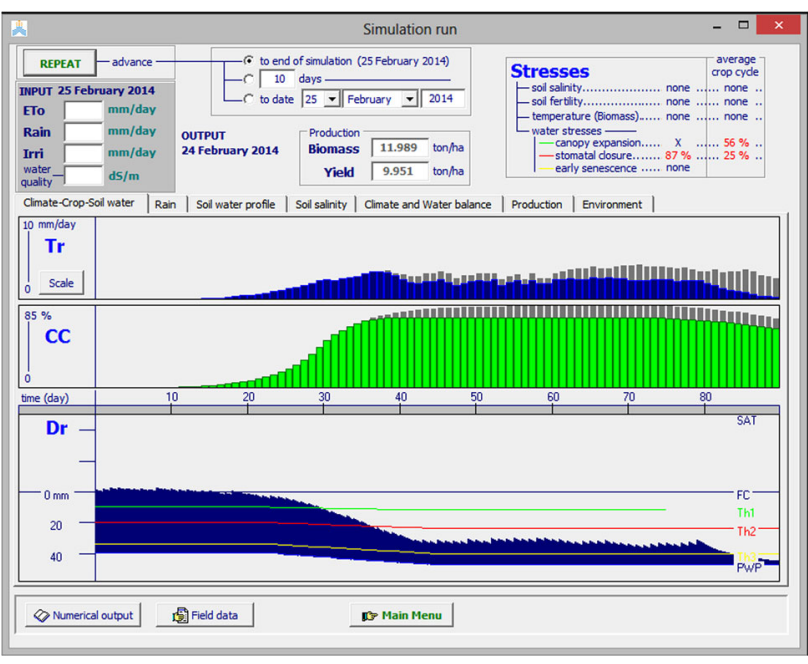

Fig. 10 Model generated transpiration, canopy cover, and soil moisture in the rootzone for schedule $\mathrm{S}_{10}$

economic ways. Since land is a shrinking resource for agriculture, the pathway for achieving this goal has to be higher productivity per unit of arable land and water. Thus, the objective of irrigation in the present era is not only to provide supplementary water for crop production but also to increase crop per drop of water. As such, the question of improving the present level of water use efficiency in general and for irrigation in particular assumes a great significance in perspective water resource planning.

AquaCrop model proved its capability in simulating canopy cover, biomass and yield. The AquaCrop model was calibrated for daily irrigation schedule at $100 \%$ ETc. The calibrated model parameters, i.e., initial canopy cover, harvesting index, and water productivity, were observed as $0.67,80 \%$, and $21 \mathrm{~g} \mathrm{~m}^{-2}$, respectively.

Ten alternative irrigation schedules were formulated for mulch and non-mulch condition. These alternative irrigation schedules were optimized on the basis of water use efficiency. Simulations were carried out with calibrated AquaCrop model for the period November 27, 2013 to February 20, 2014. WUE efficiency is found maximum for schedule $\mathrm{S}_{10}$ with high reduction in the yield as $21.20 \%$, while schedule $\mathrm{S}_{8}$ saved $25.19 \%$ water, with only $4.63 \%$ reduction in the yield of cabbage head. Therefore, it is suggested to undertake cabbage production under polyethylene mulch with drip irrigation having daily irrigation schedule fixed at $80 \%$ of ETc.

\section{Implications}

Among the developed alternative irrigation schedules, the schedule $\mathrm{S}_{8}$, which can explained as irrigation scheduling at $80 \%$ of crop evapotranspiration (ETc) under polyethylene mulch with drip irrigation, was observed to be the best as compared to existing schedule in terms of WUE. By implementing the selected schedules for cabbage, increase in water productivity as well as water saving can be achieved.

As performance of delivery schedule was assessed based on water use efficiency estimated using the computer software tool AquaCrop, it needs to be validated on field scale to confirm the actual variation in observed values of this study.

Open Access This article is distributed under the terms of the Creative Commons Attribution 4.0 International License (http:// creativecommons.org/licenses/by/4.0/), which permits unrestricted use, distribution, and reproduction in any medium, provided you give appropriate credit to the original author(s) and the source, provide a link to the Creative Commons license, and indicate if changes were made.

\section{References}

1. Abedinpour M, Sarangi A, Rajput TBS, Singh Man, Pathak H, Ahmad T (2012) Performance evaluation of AquaCrop model for maize crop in a semi-arid environment. Agric Water Manag 110:55-66

2. Allen RG, Pereira LS, Raes D, Smith M (1998) Crop evapotranspiration: Guidelines for computing crop requirements, Irrigation and Drainage Paper No. 56, Food and Agriculture Organization, Rome, p 300

3. Andarzian A, Bannayan M, Steduto P, Mazraeh H, Barati ME, Barati MA, Rahnama A (2011) Validation and testing of the AquaCrop model under full and deficit irrigated wheat production in Iran. Agric Water Manag 100:1-8

4. Araya A, Habtu S, Hadgu KM, Kebede A, Dejene T (2010) Test of AquaCrop model in simulating biomass and yield of water deficient and irrigated barley (Hordeum vulgare). Agric Water Manag 97:1838-1846

5. Doorenbos J, Pruitt WJ (1977) Guidelines for predicting crop water requirements. Irrigation and Drainage Paper No. 24, FAO, Rome

6. Doorenbos J, Kassam AH, Bentvelsen CIM (1979) Yield response to water. Food and Agriculture Organization of the United Nations, Rome

7. Droogers P, Hunink J (2012) Assessment of impact of climate change on Wheat in Armenia, Azerbaijan and Georgia. Regional Analytical and Advisory Activities Program on Developing Adaptation and Mitigation Strategies in the Agricultural Sector for Armenia, Azerbaijan and Georgia. Future Water, 1-42

8. Heng LK, Hsiao T, Evett S, Howell T, Steduto P (2009) Validating the FAO AquaCrop model for irrigated and water deficient field maize. Agron J 101:488-498

9. Holsambare DG (1988) Thibak Sinchan Tantra. Continental Prakashan, Vijay Nagar, Pune, pp 1-61

10. Hsiao TC, Heng L, Steduto P, Rojas-Lara B, Raes D, Fereres E (2009) AquaCrop-The FAO crop model to simulate yield response to Water: III. Parameterization and testing for maize. Agron J 101:448-459

11. Hunink JE, Droogers P (2011) Climate Change Impact Assessment on Crop Production in Uz-bekistan. World Bank Study on Reducing Vulnerability to Climate Change in Europe and Central Asia (ECA) Agricultural Systems, Future Water

12. Michael AM (1974) Irrigation engineering: theory and practice. Vikas Publishing House, New Delhi, p 457 
13. Nash JE, Sutcliffe JV (1970) River flow forecasting through conceptual models part $1-\mathrm{a}$ discussion of principles. J Hydrol 10:282-290

14. National Horticulture Board (2013) Statewise, area, production and productivity of cabbage. http://nhb.gov.in/area-pro/Indian\% 20Horticulture\%202013.pdf

15. Nyatuame M, Ampiaw F, Owusu-Gyimah V and Ibrahim BM (2013). Irrigation scheduling and water use efficiency on cabbage yield. Int J Agronomy Agric Res ISSN: 2223-7054

16. Stricevic R, Cosic M, Djurovic N, Pejic B, Maksimovic L (2011) Assessment of the FAO AquaCrop model in the simulation of rainfed and supplementally irrigated maize, sugar beet and sunflower. Agric Water Manag 98:1615-1621
17. Tiwari KN, Mal PK (2003) Effect of drip irrigation on yield of cabbage (Brassica oleracea L.var. capitata) under mulch and non-mulch condition. Agric Water Manag 58:19-28

18. Wellens J, Raes D, Traore F, Denis A, Djaby B, Tychon B (2013) Performance assessment of the FAO AquaCrop model for irrigated cabbage on farmer plots in a semi-arid environment. Agric Water Manag 127:40-47

19. Whisler FD, Acock B, Baker DN, Fye RE, Hodges HF, Lambert JR, Lemmon HE, Mc Kinion JM, Reddy VR (1986) Crop simulation models in agronomic systems. Adv Agron 40:141-208 